\title{
A Holocene record of environmental change from Río Zeballos, central Patagonia
}

\author{
Robert D McCulloch,' Maria J Figuerero Torres, ${ }^{2}$ \\ Guillermo L Mengoni Goñalons, ${ }^{2}$ Rebecca Barclay' \\ and Claudia Mansilla'
}

\begin{abstract}
There are few continuous palaeoenvironmental records spanning the Holocene in Andean Southern Patagonia near the Northern Patagonian Ice Field $\left(\sim 47^{\circ} \mathrm{S}\right)$. Insights into the environmental context for human-landscape interactions have relied mostly on data extrapolated from distant extra-Andean locations that suggest limited environmental change during the Holocene. La Frontera $\left(46^{\circ} 52^{\prime} \mathrm{S}\right)$, a high altitude site on the southern beech forest-steppe ecotone boundary in the Río Zeballos valley, provides lithostratigraphical and palaeoecological evidence, constrained by ${ }^{14} \mathrm{C}$ dating and tephrochronology, for dynamic environmental change during the last $\sim 8000$ years. An initial amelioration in environmental conditions after $\mathrm{c}$. 82 I 0 cal. BP was followed by a reversal to colder conditions between c. 7420 and 6480 cal. BP, coincident with initial human occupation within the Paso Roballos and Lago Pueyrredón basin. Between c. 6480 and $3700 \mathrm{cal}$. BP, the woodland/steppe composition continued to fluctuate in response to climatic change. After c. $3700 \mathrm{cal}$. BP, a gradual shift to more stable and temperate conditions, punctuated by increased fire activity, is contemporary with the later phases of human occupation extending up into the Paso Roballos-Río Zeballos corridor.
\end{abstract}

\section{Keywords}

central Patagonia, Holocene, palaeoenvironments, pollen analysis, tephrochronology

Received 8 March 2016; revised manuscript accepted 3 October 2016

\section{Introduction}

A growing body of palaeoenvironmental evidence from southern South America, particularly Patagonia $\left(\sim 38-56^{\circ} \mathrm{S}\right)$, points towards a region that experienced significant climate change during the last glacial/interglacial transition (LGIT, c. 18,000-11,500 cal. BP). Palaeoecological studies, principally pollen analysis to reconstruct past vegetation changes, have allowed us to infer the dramatic nature of the climate changes during the LGIT (e.g. Heusser, 1995; McCulloch and Davies, 2001; Markgraf et al., 2007; Moreno, 1997; Moreno and León, 2003).

However, there are few continuous palaeoenvironmental records spanning the Holocene in Andean Southern Patagonia near the Northern Patagonian Ice Field $\left(\sim 47^{\circ} \mathrm{S}\right)$. Insights into the environmental context for human-landscape interactions have mostly relied on data extrapolated from distant extra-Andean and lower altitude locations (De Porras et al., 2012, 2014; Gilli et al., 2005; Horta et al., 2016; Mancini et al., 2005; Markgraf et al., 2007; Villa-Martínez et al., 2012). Most palaeoecological proxies require sufficient moisture to ensure continued sediment accumulation and preservation. In Central Patagonia, the west-east precipitation gradient is very steep. Therefore, the majority of extant records are geographically close to the higher precipitation along the southern Andes. The impression given by the majority of these high-resolution studies from Patagonia is that the Holocene (c. 11,500 cal. BP to present) in central Patagonia is a period where the vegetation is dominated by Nothofagus (southern beech) and characterised by few changes in the vegetation cover of the landscape. Further north in the Archipiélago de los Chonos, Haberle and Bennett (2004) and at Lago Mallín Pollux, near
Balmaceda, Markgraf et al. (2007) infer a shift to higher levels of effective moisture after $c .7500 \mathrm{cal}$. BP and such conditions persisted to the present. In contrast to these relatively 'stable' Holocene records, there are others that indicate sub-millenial scale variability in the latitudinal position and intensity of the southern westerly winds (SWWs) during the Holocene (e.g. Gilli et al., 2005; Moy et al., 2008).

Within the study area, four archaeological sequences allow us to assess the extent to which the area was occupied by mobile hunter-gatherers in the past and the intensity of place use. The dates for human occupations come from the stratigraphical sequences at four locations (Figure 1). The Sol de Mayo I (660 m a.s.l.) and Colmillo Sur I (730 m a.s.1.) rock shelters and the Lago Columna I (600 $\mathrm{m}$ a.s.1.) cave are all located in the Ghio-Columna river catchment in Paso Roballos. The Alero Mauricio II (670 m a.s.l.) rock shelter is situated further north in the Zeballos-Jeinemeni river catchment. A synthesis of available dates for occupation of sites within the Jeinemeni-Ghio corridor suggests four periods of occupation from 7150 to 6795,3455 to 2015,1260 to

\footnotetext{
'Biological and Environmental Sciences, University of Stirling, Scotland ${ }^{2}$ Instituto de Arqueología, Facultad de Filosofía y Letras, Universidad de Buenos Aires, Argentina
}

\section{Corresponding author:}

Robert D McCulloch, Biological and Environmental Sciences, University of Stirling, Stirling FK9 4LA, Scotland.

Email: robert.mcculloch@stir.ac.uk 


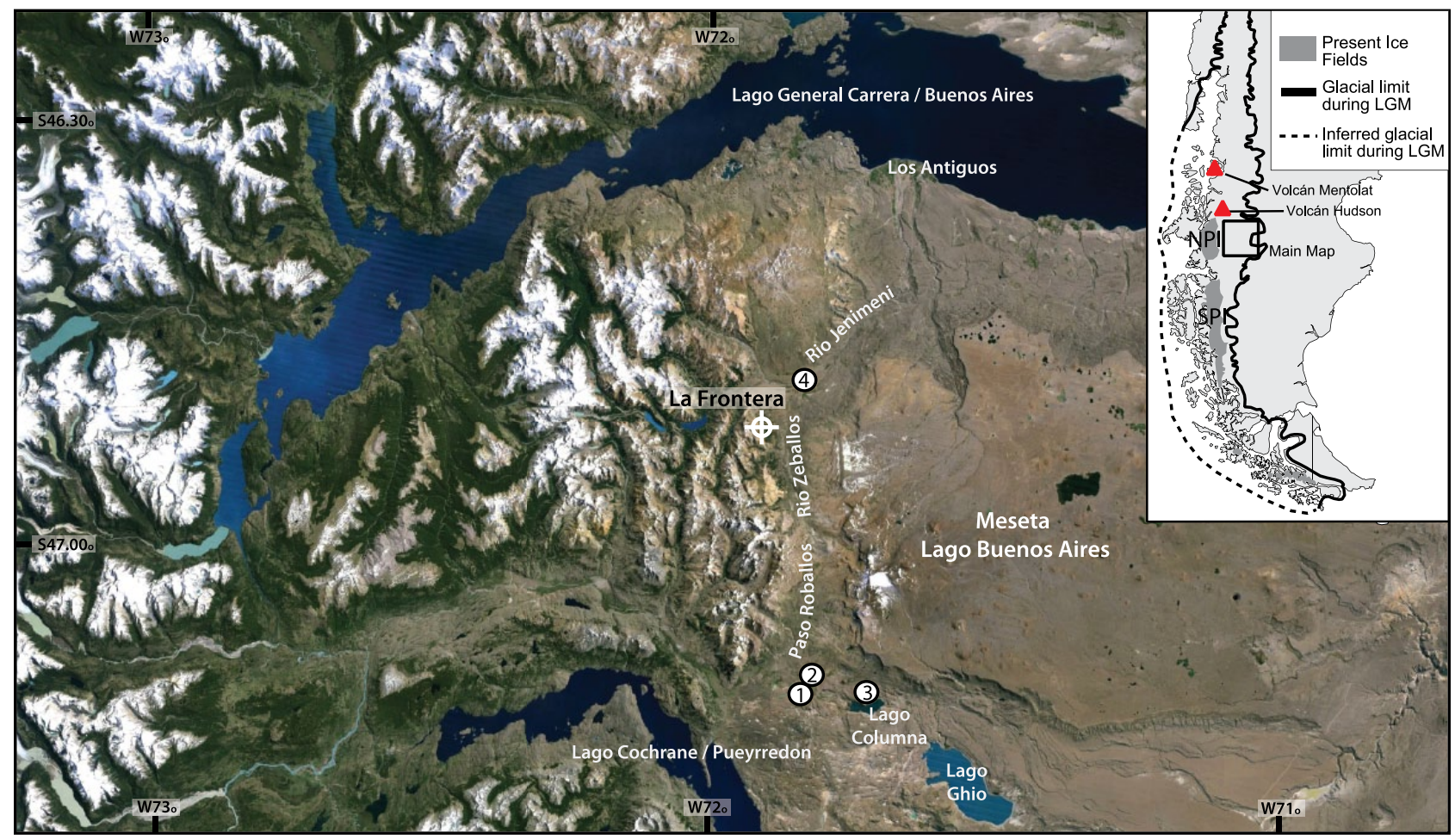

Figure I. Study area and places indicated in the text. The inset map indicates the location of the study area within Patagonia.Archaeological sites indicated (I) Sol de Mayo I, (2) Colmillo Sur I, (3) Lago Columna I and (4) Alero Mauricio II. Image from Google Earth.

730 and 470 to 315 cal. BP ( $2 \sigma$ ages recalibrated using SHcal13 Hogg et al., 2013; Mengoni Goñalons et al., 2013). The Jeinemeni and Zeballos valley was occupied from the end of the mid-Holocene (c. 3000 cal. BP), whereas the occupation history of Paso Roballos starts earlier (c. 7000 cal. BP).

The intensity of occupation was measured by changes in the frequencies of rock and mineral raw materials used for on-site knapping of tools, and in lithic artefact assemblage composition (Mengoni Goñalons et al., 2013). While archaeofaunal assemblages were dominated by guanaco (Lama guanicoe), a species that is ubiquitous in all the contexts analysed. Places may have been occupied for different lengths of time and then abandoned, but sites in the southern portion of the corridor were more persistently occupied and the intensity of place use shows variations over time (Figuerero Torres and Mengoni Goñalons, 2010; Mengoni Goñalons et al., 2013).

To explore the timing and nature of environmental changes within the Jeinemeni-Ghio corridor, we present a reconstruction of the vegetation using pollen analysis of sediments from a high altitude small closed basin located above the valley floor. The palaeoenvironmental record provides an insight into the landscape, climatic conditions and the potential resources offered to the hunter-gatherers during the periods of occupation.

\section{The study area}

The study area comprises a north-south corridor which follows the frontier between Argentina and Chile between 46 $30^{\prime} \mathrm{S}$ and $47^{\circ} 10^{\prime} \mathrm{S}$ (Figure 1). The corridor can be divided into two subareas: (a) the northern part, which ranges from the southern shore of Lago Buenos Aires at Los Antiguos southwards along the Jeinemeni and Zeballos basin, and (b) the southern area of Paso Roballos containing the basin of Lago Ghio. The corridor lies between the higher grounds of the Meseta del Lago Buenos Aires (1400-1900 m a.s.l.) to the east and the cordilleran mountains (2300-2700 $\mathrm{m}$ a.s.1.) to the west and probably formed a natural route-way for people to move between the larger lake basins to the north and south (200-600 m a.s.1.). The Ghio valley is part of the large ancient glacial valley that also holds Lago Pueyrredón.

The Patagonian climate system is dominated by the role of the SWWs, a zone of storm tracks that produce high levels of rainfall over the Andes and sustain the maritime ice fields along the southern Andes and the Cordillera Darwin (Garreaud et al., 2013). The SWWs migrate seasonally in response to wintersummer changes in the extent of Antarctic sea ice and latitudinal pressure changes and so precipitation is distributed across a large latitudinal range (McCulloch, 2011). The orographic nature of the rainfall over the Andes produces a hyper-humid environment along the western flanks of the southern Andes and semi-arid conditions in the eastern lee of the mountains. The current vegetation patterns of Patagonia closely reflect the spatial distribution of precipitation and the latitudinal temperature gradient. The west-east precipitation gradient is markedly steep in the study area in the rain-shadow of the North Patagonian ice fields. The steep precipitation gradient is evidenced in the short $(\sim 100 \mathrm{~km})$, longitudinal distance from temperate woodland (Nothofagus pumilio and Nothofagus antarctica) to the west to the drier steppe vegetation to the east.

\section{Materials and methods}

A 300-cm profile was sampled using a D-section Russian corer (Jowsey, 1966) from a kettle hole located at $46^{\circ} 52^{\prime} 11.94^{\prime \prime} \mathrm{S}$, $71^{\circ} 52^{\prime} 37.63^{\prime \prime} \mathrm{W}$ and at an altitude of $997 \mathrm{~m}$ a.s.l. within Estancia La Frontera. The basin is located $41 \mathrm{~km}$ south of the town of Los Antiguos and above the Río Zeballos valley (Figure 1). The core sections were sealed in layflat tubing and returned to the Palaeoenvironmental Laboratory at the University of Stirling for analysis. Cores are stored at a constant $4{ }^{\circ} \mathrm{C}$ to inhibit microbial activity.

The stratigraphy of the core was photographed in the field and the sediments described. The gross-stratigraphy is characterised by loss-on-ignition. Contiguous samples were dried at $105^{\circ} \mathrm{C}$ and then combusted at $550^{\circ} \mathrm{C}\left(\mathrm{LOI}_{550}\right)$. The gross-stratigraphy is presented in Figure 2. 


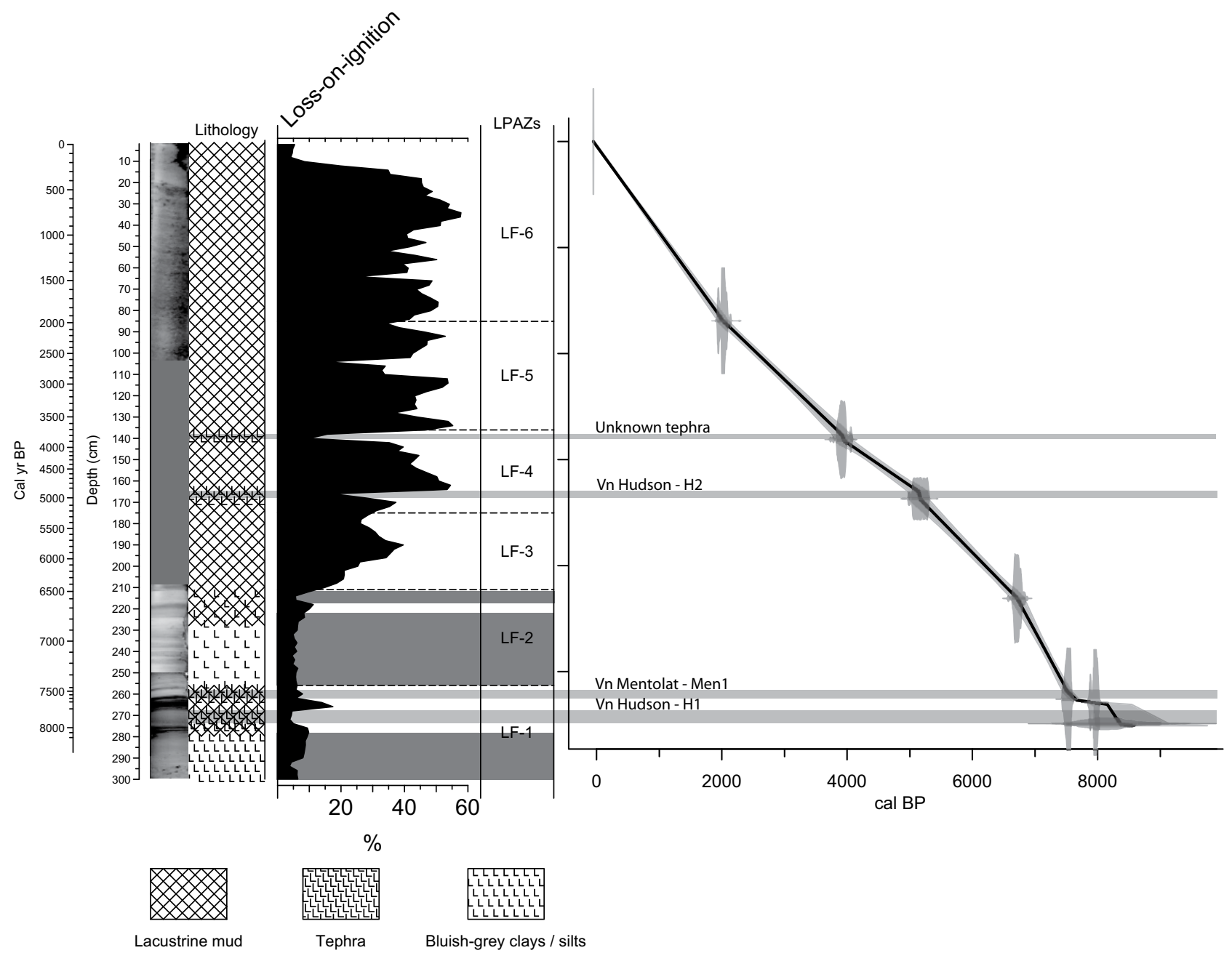

Figure 2. Gross stratigraphy of the La Frontera core and percentage organic content. Tephra layers and location of ${ }^{14} \mathrm{C}$ dates are indicated and the age-depth model calculated using CLAM Rev. 2.2 (Blaauw, 2010).

Fossil pollen samples were prepared using standard pollen preparation procedures including Sodium hydroxide and Acetolysis (Moore et al., 1991). The use of Hydrofluoric acid was restricted for the basal bluish-grey clay and silt rich sediments to preserve any tephra particles in the pollen samples. To enable the assessment of the total concentrations of pollen in each sample, tablets containing Lycopodium clavatum spores of known concentration were added to each sample and the spores counted alongside the fossil pollen (Stockmarr, 1971). Pollen, aquatic and cryptogrammic spores and charcoal particles $(<180 \mu \mathrm{m})$, were identified to a Total Land Pollen (TLP) sum of $>300$ using an Olympus BX43 light microscope at $\times 400$ magnification with critical identifications made at $\times 800$ and assisted by a pollen reference collection and photomicrographs (Heusser, 1971; Markgraf and D'Antoni, 1978; Moore et al., 1991). Local pollen assemblage zones (LPAZs) were identified based on major Land Pollen changes, stratigraphy and supported by stratigraphically constrained cluster analysis (Grimm, 1987). The percentage pollen is presented in Figure 3 and pollen and charcoal accumulation rates are presented in Figure 4.

To provide information about the depositional environment of the pollen, each grain was assessed for its state of preservation using five categories: normal, broken, crumpled, corroded and degraded (Berglund and Ralska-Jasiewiczowa, 1986; Tipping, 1987). Grains that are broken and/or crumpled are likely to indicate damage due to mechanical processes such as through abrasion during transport. Pollen is best preserved in waterlogged (anaerobic) and acidic conditions and so corrosion and degradation suggest chemical processes whereby pollen is 'digested' by microbial activity under drier aerobic conditions. The assessment of the state of preservation of the pollen grains also has the dual purpose of indicating the extent of taphonomic alteration of the original pollen assemblage. A high level of degradation of the pollen may result in the differential preservation of pollen that is more resistant such as grains of Asteraceae subf. Cichorioideae and spores of Polypodiaceae and the loss of more fragile pollen such as Cyperaceae (Bunting and Tipping, 2000). The pollen preservation results are presented in Figure 4.

\section{Sediment stratigraphy}

The basal sediments, 300-278 cm, comprise bluish-grey clays and silts. At $278-274 \mathrm{~cm}$, there are fine sub-centimetre black layers, identified as charcoal, intercalated with the bluish-grey clays and silts. The basal bluish-grey clays and silts are then overlain by a 6-cm dark olive-green coarse silt and fine sand layer (274-268 $\mathrm{cm}$ ) which has been identified as a tephra layer. Above the tephra layer is a further layer of dark brown-blackish organic mud with lenses of fine clay and silt within $(268-262 \mathrm{~cm})$. The organic mud is overlain, $262-258 \mathrm{~cm}$, by a creamy-white fine silt layer, with a thin (sub-centimetre) layer of brown organic mud above. Between 258 and $211 \mathrm{~cm}$, there are bluish-grey clays and fine silts with sub-millimetre horizontal banding. Between 224 and $218 \mathrm{~cm}$, there is layer of pale-brown mud, increasing in organic content upwards to a sharp contact with more bluish-grey clays and fine silts above. 


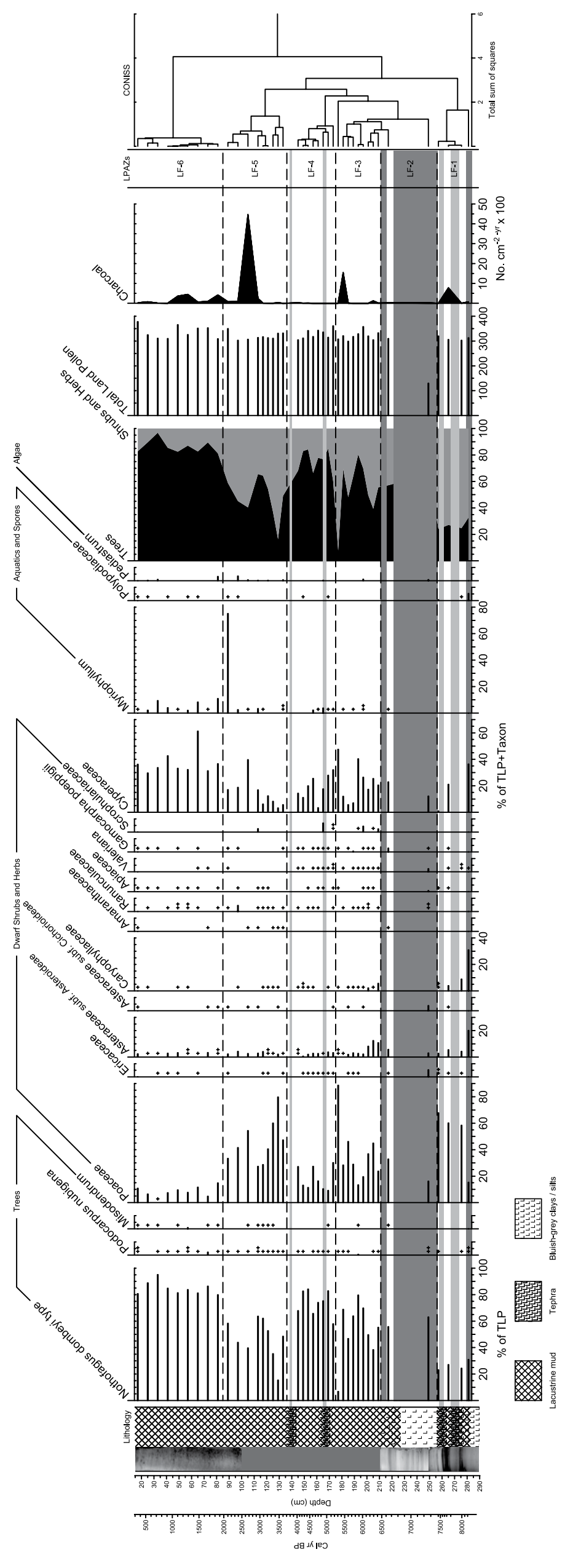

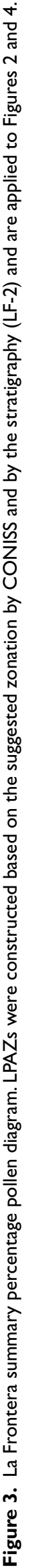




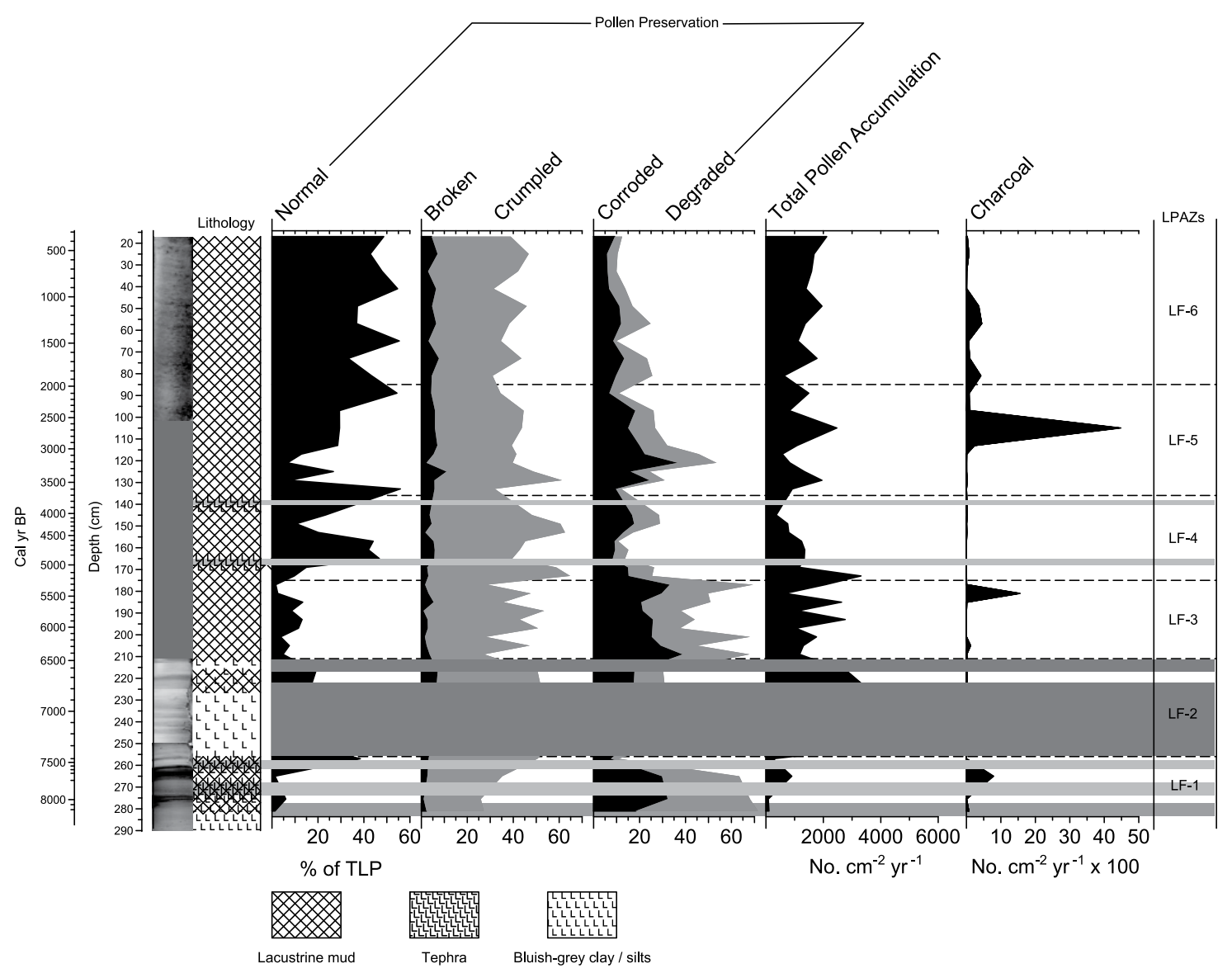

Figure 4. La Frontera summary pollen preservation diagram (includes only land pollen taxa), total land pollen and charcoal accumulation rates.

At $211 \mathrm{~cm}$, there is a sharp increase in organic content and the remaining core stratigraphy is characterised by a fine organic mud with varying proportions of organic content $\left(\mathrm{LOI}_{550}: 55-35 \%\right)$. At $168-165$ and $138-140 \mathrm{~cm}$, there are two discrete fine silt layers which have been identified as tephra layers. A further diffuse mineral layer at 106-104 cm was found to comprise diatoms and mineral inwash material. There is also a significant reduction in organic content at the very top of the core, between 8 and $3 \mathrm{~cm}$.

\section{Tephrochronology}

Larger tephra layers were visually identified in the core stratigraphy and microscopic tephra layers were located in the $\mathrm{LOI}_{550}$ profile and within pollen samples. Tephra samples were extracted using a Sulphuric acid digestion process accelerated by the addition of small quantities of Nitric acid while simmering on a hotplate (Dugmore et al., 1992). The isolated mineral residue was washed in distilled water and studied optically. We particularly focused on the concentrations of volcanic glass based on shard morphology, vesicularity and isotropism under plane-polarised light. The geochemical composition of the glass component of tephra has been found to be consistent over distance from the source volcano (Dugmore et al., 1995; Hunt and Hill, 1993).

Four tephra samples were isolated at 274-268, 262-258, $168-165$ and $140-138 \mathrm{~cm}$. The tephra was mounted, ground and polished to $75-\mu \mathrm{m}$ thickness for Electron Microprobe Analysis. Individual glass shards were targeted for the analysis of 10 major elements $\left(\mathrm{Na}_{2} \mathrm{O}, \mathrm{MgO}, \mathrm{Al}_{2} \mathrm{O}_{3}, \mathrm{~K}_{2} \mathrm{O}, \mathrm{CaO}, \mathrm{FeO}, \mathrm{SiO}_{2}\right.$, $\mathrm{P}_{2} \mathrm{O}_{5}, \mathrm{TiO}_{2}, \mathrm{MnO}$ ) with $3-\mu \mathrm{m}$ beam condition of $15 \mathrm{kV}$ and $2 \mathrm{nA}$ (Hayward, 2011). A minimum of 10 glass analyses was accepted to characterise geochemically a layer (Hunt and Hill, 1993) (Table 1).

\section{Chronology}

The chronology of the core is constrained by five AMS ages and supplemented by the chronostratigraphic correlation of four regional tephra layers (Table 2). The radiocarbon ages were calibrated to calendar years using CALIB 7.10 SHcal13 (Hogg et al., 2013; Stuiver and Reimer, 1993).

The tephra layer at $268-274 \mathrm{~cm}$ is geochemically fingerprinted to the large eruption of Volcán Hudson (H1) (Naranjo and Stern, 1998, 2004; Prieto et al., 2013; Stern et al., 2016). The maximum age for $\mathrm{H} 1$ of $7241 \pm 23{ }^{14} \mathrm{C}$ yr BP used here (Stern et al., 2016) is older than that of $6890 \pm 100{ }^{14} \mathrm{C}$ yr BP, given by Prieto et al. (2013), but, as a similar exercise for the Volcán Reclus R1 layer has demonstrated, improved accuracy may be achieved by selecting ages from higher-resolution sediment and peat cores (McCulloch and Bentley, 1998; McCulloch et al., 2005). The older age of $7241 \pm 23{ }^{14} \mathrm{C}$ yr BP is also consistent with the minimum age for $\mathrm{H} 1$ of $7176 \pm 38{ }^{14} \mathrm{C}$ yr BP from La Frontera.

The second tephra layer at $262-258 \mathrm{~cm}$ is visually and stratigraphically correlated to an eruption of Volcán Mentolat (Men1) as reduction of the tephra layer to clay/silt particles prevented electron microprobe analysis of the glass component. The Men1 tephra layer is dated to $6895 \pm 20{ }^{14} \mathrm{C} \mathrm{yr} \mathrm{BP}$ (Stern et al., 2016). The third tephra layer at $165-168 \mathrm{~cm}$ is geochemically fingerprinted to the eruption of $\mathrm{H} 2$ (Volcán Hudson) and is dated here to a maximum age of $4545 \pm 35{ }^{14} \mathrm{C}$ yr BP. Current ${ }^{14} \mathrm{C}$ dating for the $\mathrm{H} 2$ tephra layer found elsewhere has a broad age range (Stern et al., 2016) and so this ${ }^{14} \mathrm{C}$ date further helps to constrain the timing of this eruption. The fourth tephra layer at $138-140 \mathrm{~cm}$ has a mafic geochemistry and its source is at present unknown (C Stern, personal communication, 2015). The maximum timing of the eruption is here dated to $3654 \pm 35{ }^{14} \mathrm{C}$ yr BP.

To constrain the palaeoenvironmental record from La Frontera, the combined AMS and tephrochronology (Table 2) was 
Table I. Major element analyses of the glass component of the La Frontera tephra layers.

\begin{tabular}{|c|c|c|c|c|c|c|c|c|c|c|}
\hline $\mathrm{SiO}_{2}$ & 53.95 & 53.65 & 53.64 & 53.50 & 53.37 & 53.29 & 53.23 & 53.15 & 52.89 & 52.57 \\
\hline $\mathrm{TiO}_{2}$ & 1.91 & 1.73 & 1.47 & 0.92 & 1.52 & 1.02 & 1.50 & 1.86 & 1.89 & 1.85 \\
\hline $\mathrm{Al}_{2} \mathrm{O}_{3}$ & 15.24 & 14.72 & I5.37 & 20.18 & 16.25 & 19.66 & 16.28 & 14.47 & 13.77 & 13.60 \\
\hline $\mathrm{FeO}$ & 10.45 & 11.80 & 10.67 & 6.03 & 8.77 & 7.40 & 9.44 & 10.48 & 10.86 & 10.99 \\
\hline $\mathrm{MnO}$ & 0.19 & 0.20 & 0.19 & 0.08 & 0.16 & 0.11 & 0.17 & 0.20 & 0.19 & 0.20 \\
\hline $\mathrm{MgO}$ & 3.58 & 4.11 & 4.55 & 3.27 & 5.53 & 3.05 & 4.87 & 4.16 & 4.48 & 4.51 \\
\hline $\mathrm{CaO}$ & 8.20 & 7.47 & 8.27 & 10.88 & 10.07 & 10.07 & 9.00 & 8.49 & 8.63 & 8.55 \\
\hline $\mathrm{Na}_{2} \mathrm{O}$ & 3.96 & 3.75 & 3.45 & 3.91 & 3.59 & 3.69 & 3.95 & 3.95 & 3.79 & 4.00 \\
\hline $\mathrm{K}_{2} \mathrm{O}$ & 1.69 & 2.08 & 1.66 & 0.84 & 0.95 & 1.04 & 1.56 & 1.75 & 1.81 & 1.83 \\
\hline $\mathrm{P}_{2} \mathrm{O}_{5}$ & 0.49 & 0.38 & 0.36 & 0.19 & 0.33 & 0.23 & 0.35 & 0.41 & 0.45 & 0.44 \\
\hline Total & 99.67 & 99.90 & 99.63 & 99.81 & 100.55 & 99.55 & 100.35 & 98.93 & 98.74 & 98.55 \\
\hline \multicolumn{11}{|c|}{ 165-168 cm Volcán Hudson - H2 (4545 $\pm 35{ }^{14} \mathrm{C}$ yr BP $)$} \\
\hline $\mathrm{SiO}_{2}$ & 70.54 & 69.93 & 68.41 & 68.32 & 68.27 & 68.19 & 67.95 & 67.57 & 67.46 & 66.88 \\
\hline $\mathrm{TiO}_{2}$ & 0.87 & 0.96 & 0.88 & 0.87 & 0.88 & 0.85 & 0.87 & 0.86 & 0.88 & 0.87 \\
\hline $\mathrm{Al}_{2} \mathrm{O}_{3}$ & 15.92 & $|4.4|$ & 15.21 & $|4.9|$ & 15.66 & 14.92 & 15.39 & 15.14 & 15.29 & 15.19 \\
\hline $\mathrm{FeO}$ & 3.78 & 3.22 & 3.53 & 3.41 & 3.38 & 3.43 & 3.74 & 3.26 & 3.41 & 3.64 \\
\hline $\mathrm{MnO}$ & 0.13 & 0.11 & 0.13 & 0.11 & 0.13 & 0.12 & 0.13 & 0.12 & 0.13 & 0.13 \\
\hline $\mathrm{MgO}$ & 0.88 & 0.61 & 0.88 & 0.84 & 0.81 & 0.82 & 0.92 & 0.85 & 0.87 & 0.83 \\
\hline $\mathrm{CaO}$ & 2.00 & 1.63 & 2.03 & 2.04 & 1.85 & 1.96 & 2.09 & 1.97 & 1.90 & 1.93 \\
\hline $\mathrm{Na}_{2} \mathrm{O}$ & 0.55 & 5.63 & 5.57 & 5.58 & 5.59 & 5.77 & 5.71 & 5.66 & 5.84 & 5.64 \\
\hline $\mathrm{K}_{2} \mathrm{O}$ & 2.54 & 3.33 & 3.30 & 3.19 & 3.24 & 3.54 & 3.17 & 3.44 & 3.33 & 3.34 \\
\hline $\mathrm{P}_{2} \mathrm{O}_{5}$ & 0.15 & 0.17 & 0.14 & 0.15 & 0.15 & 0.14 & 0.15 & 0.14 & 0.13 & 0.16 \\
\hline Total & 97.36 & 100.01 & 100.07 & 99.42 & 99.94 & 99.74 & 100.13 & 99.01 & 99.24 & 98.61 \\
\hline \multicolumn{11}{|c|}{ 268-274 cm Volcán Hudson - HI $\left(724 \mathrm{I} \pm 23{ }^{14} \mathrm{C}\right.$ yr BP $)$} \\
\hline $\mathrm{SiO}_{2}$ & 65.79 & 65.77 & 65.7I & 65.11 & 64.96 & 64.94 & 64.40 & 64.22 & 64.14 & 63.61 \\
\hline $\mathrm{TiO}_{2}$ & 1.14 & 1.16 & 1.17 & 1.14 & 1.13 & 1.28 & 1.18 & 1.19 & 1.26 & 1.29 \\
\hline $\mathrm{Al}_{2} \mathrm{O}_{3}$ & 15.52 & 15.67 & 15.52 & 15.56 & 15.34 & 15.72 & 15.50 & 16.15 & $15.6 \mid$ & 15.14 \\
\hline $\mathrm{FeO}$ & 4.30 & 4.52 & 4.62 & 4.38 & 4.64 & 5.23 & 4.61 & 4.78 & 5.06 & 5.03 \\
\hline $\mathrm{MnO}$ & 0.15 & 0.16 & 0.16 & 0.16 & 0.14 & 0.15 & 0.16 & 0.16 & 0.16 & 0.16 \\
\hline $\mathrm{MgO}$ & 1.19 & 1.18 & 1.18 & 1.16 & 1.17 & 1.56 & 1.34 & 1.22 & 1.54 & 1.50 \\
\hline $\mathrm{CaO}$ & 2.51 & 2.60 & 2.73 & 2.57 & 2.51 & 3.25 & 2.93 & 3.00 & 3.04 & 3.05 \\
\hline $\mathrm{Na}_{2} \mathrm{O}$ & 5.76 & 5.92 & 5.86 & 5.86 & 6.22 & 2.86 & 5.81 & 6.07 & 5.79 & 5.84 \\
\hline $\mathrm{K}_{2} \mathrm{O}$ & 3.03 & 2.98 & 2.87 & 2.84 & 2.90 & 2.64 & 2.73 & 2.78 & 2.77 & 2.75 \\
\hline $\mathrm{P}_{2} \mathrm{O}_{5}$ & 0.26 & 0.24 & 0.27 & 0.23 & 0.24 & 0.34 & 0.28 & 0.31 & 0.31 & 0.33 \\
\hline Total & 99.66 & 100.19 & 100.09 & 99.00 & 99.25 & 97.96 & 98.95 & 99.89 & 99.68 & 98.71 \\
\hline
\end{tabular}

Table 2. Radiocarbon dates and ages for tephra layers correlated to the La Frontera record. ${ }^{14} \mathrm{C}$ dates have been calibrated using CALIB Rev. 7.I0 and shcal 13.14c (Hogg et al., 2013; Stuiver and Reimer, 1993).

\begin{tabular}{|c|c|c|c|c|c|}
\hline Depth (cm) & Material & ${ }^{14} \mathrm{C}$ yr BP $(\mathrm{I} \sigma)$ & $\delta^{13} \mathrm{C}_{\mathrm{VPDB}} \%$ & Cal. BP $(I \sigma)$ & Lab code \\
\hline $0-1$ & Core sampled in 2010 & & & & \\
\hline $84-85$ & Bulk & $2095 \pm 29$ & -27.6 & $1938-2078$ & SUERC-54486 \\
\hline $138-140$ & Unknown eruption & & & & \\
\hline$|40-14|$ & Bulk & $3654 \pm 35$ & -28.9 & $3870-3975$ & SUERC-49368 \\
\hline $165-168$ & Volcán Hudson $(\mathrm{H} 2)$ & & & & \\
\hline $168-169$ & Bulk & $4545 \pm 35$ & -30.6 & $5054-5286$ & SUERC-49369 \\
\hline $215-216$ & Bulk & $5940 \pm 37$ & -31.7 & $6667-6774$ & SUERC-49367 \\
\hline \multirow[t]{2}{*}{$258-262$} & Mentolat (Men I) & & & & \\
\hline & & $6895 \pm 20^{\mathrm{a}}$ & $\mathrm{n} / \mathrm{a}$ & $7628-7713$ & $\mathrm{n} / \mathrm{a}$ \\
\hline $264-265$ & Bulk & $7176 \pm 38$ & -25.4 & $7935-8000$ & SUERC-49366 \\
\hline \multirow[t]{2}{*}{$268-274$} & Volcán Hudson $(\mathrm{HI})$ & & & & \\
\hline & & $724 I \pm 23^{a}$ & $\mathrm{n} / \mathrm{a}$ & $797|-802|$ & $\mathrm{n} / \mathrm{a}$ \\
\hline
\end{tabular}

aSource: Stern et al. (2016). 
used to produce a calibrated age-depth model using the programme CLAM Rev. 2.2 (Blaauw, 2010) and the weighted mean age was used for each centimetre depth (Figure 2). The events of instantaneous deposition (i.e. the tephra layers) are included in the age-depth model.

\section{Pollen stratigraphy}

The basal bluish-grey clays and fine silts did not yield sufficient pollen to achieve a TLP sum.

\section{LPAZ LF-I (300-258 cm; c. 82 I0-7420 cal. BP)}

The intermittent nature of the pollen spectra in this zone, so closely sandwiched between the basal clays and silts with the overlying clays and silts of LPAZ LF-2 and the inclusion of the H1 and Men1 tephra layers, restricts the characterisation of the vegetation at the time of the onset of accumulation at the site. The basal pollen assemblage suggests a forest-steppe ecotone margin with Nothofagus dombeyi type ( $25 \%$ ) (hereafter simply referred to as Nothofagus) and dryland taxa of Asteraceae $(\sim 20 \%)$, Poaceae $(\sim 15 \%)$, Caryophyllaceae $(25 \%)$ and Cyperaceae $(\sim 35 \%)$. The upper two pollen samples indicate a replacement of the Asteraceae and Caryophyllaceae ground cover with a higher proportion of Poaceae $(\sim 60 \%)$. Charcoal particles were abundant in the basal organic muds beneath $\mathrm{H} 1$ and between $\mathrm{H} 1$ and the Mentolat tephra layer. The accumulation rate of pollen below $\mathrm{H} 1$ is low at the base of LPAZ LF-1 and increases to $\sim 1000$ grains $\mathrm{cm}^{-2} \mathrm{yr}^{-1}$ in the organic rich mud between $\mathrm{H} 1$ and the Mentolat tephra layer. The pollen is less well preserved in LPAZ LF-1 with $\sim 65 \%$ of pollen in a degraded or corroded state at the base of the core.

\section{LPAZ LF-2 (258-2 I I cm; c. 7420-6480 cal. BP)}

Insufficient pollen was recovered from the bluish-grey clays and silts except for one sample, which achieved a TLP sum of just over 100 . The pollen was also less well preserved $(\sim 50 \%$ crumpled) and so is reported in the diagram with caution. The lower pollen sample in LPAZ LF-2 indicates an increase in arboreal content (Nothofagus: $\sim 60 \%$ ) and a corresponding reduction in herb cover. The organic rich layer at $218-224 \mathrm{~cm}$ yielded a TLP sum of $>300$ and contained the highest accumulation rate of pollen for the entire record, with $\sim 5700$ grains $\mathrm{cm}^{-2} \mathrm{yr}^{-1}$. The composition of this assemblage indicates more arboreal cover $(\sim 60 \%)$ and Poaceae $(\sim 35 \%)$. This assemblage is very similar to the pollen spectra in LPAZ LF-3. However, the upper boundary of LPAZ LF-2 at $211 \mathrm{~cm}$ marks the end of deposition of the bluish-grey clays and silts.

\section{LPAZ LF-3 (2I I-I 75 cm; c. 6480-5230 cal. BP)}

This zone is characterised by the higher, though fluctuating, level of arboreal content ( $10 \%$ to $80 \%)$ and Poaceae $(20 \%$ to $90 \%)$. The lower levels of the zone have a small proportion of Asteraceae subf. Asteroideae. The pollen sample at the upper boundary of the LPAZ LF-3 also has very high charcoal content. The pollen was still poorly preserved with high levels of mechanical damage and moderate levels of oxidation and lower fluctuating levels of pollen accumulation.

\section{LPAZ LF-4 (I 75-136 cm; c. 5230-3700 cal. BP)}

This zone is dominated by Nothofagus ( $\sim 80 \%)$ and lower proportions of Poaceae ( $\sim 10 \%$ to $20 \%$ ) and the virtual absence of charcoal. The increase in tree pollen is supported by the higher concentration of Nothofagus pollen and diminished proportion of Poaceae. Concurrent with the rise in tree cover is an increase in the proportion of normal pollen grains after the deposition of $\mathrm{H} 2$. The gradual decline in the concentration of Nothofagus and reduction in well-preserved pollen from the middle of LPAZ LF-4 precedes the dramatic decline in tree cover at the boundary between LPAZs LF-4 and LF-5 that is reflected in the percentage data and concurrent with the deposition of a tephra layer of unknown source.

\section{LPAZ LF-5 ( $136-85$ cm; c. 3700-2020 cal. BP)}

The lower section of this LPAZ is dominated by a peak in Poaceae $\left(\sim 80 \%, \sim 1500\right.$ grains $\left.\mathrm{cm}^{-2} \mathrm{yr}^{-1}\right)$ and a marked increase in poorly preserved pollen. There follows a gradual trend in reducing Poaceae, increasing Nothofagus and Cyperaceae pollen along with the improving condition of the pollen grains. This trend is partially reflected in a reduction in the proportions of Poaceae pollen although Nothofagus numbers remain static. At $\sim 110 \mathrm{~cm}$, there is a substantial peak in the accumulation of charcoal particles contemporary with a brief peak in Poaceae. At the top of LPAZ LF-5, there is a peak in the aquatic pollen of Myriophyllum.

\section{LPAZ LF-6 (85-I5 cm; c. 2020-350 cal. BP)}

This LPAZ is characterised by the dominance of Nothofagus pollen $(\sim 80-90 \%)$ and low proportions of Poaceae and Asteraceae $(<10 \%)$. The pollen concentrations remain consistent at $\sim 1500$ grains per $\mathrm{cm}^{-2} \mathrm{yr}^{-1}$ and the grains are relatively well preserved with normal grains at $>40 \%$ and indicators of oxidising conditions consistently below $20 \%$. Cyperaceae remains stable at $\sim 30 \%$ and small proportions of Myriophyllum persist throughout the LPAZ.

\section{Discussion}

The nature and timing of the onset of early Holocene conditions is not recorded at La Frontera. Bluish-grey clays, silts and small $(<1$ $\mathrm{cm}$ ) clasts indicative of glacial-like conditions were sampled at the base with a minimum age of $>c .8210 \mathrm{cal}$. BP. This may suggest that, following the retreat of the principal Patagonian ice fields between 14,500 and $10,000{ }^{14} \mathrm{C}$ yr BP (Glasser et al., 2016), at this higher altitude ice cover persisted into the early Holocene. Alternatively, there may have been a hiatus between the melting of the montane ice/snow cover and the onset of conditions suitable for the growth and preservation of organic material.

The accumulation of organic sediments and the pollen assemblage in LF-1 (c. 8210-7420 cal. BP) suggests the approach of woodland, perhaps krummholz in character, and open ground alpine cover of Asteraceae, Caryophyllaceae and Poaceae. The site, which was likely a wetter basin, had a covering of sedges. After the deposition of the Volcán Hudson H1 tephra, the more diverse ground cover was rapidly replaced by grasses. It is unclear to what extent the deposition of the tephra affected the early vegetation cover or whether the continued temperate climate enabled a succession in the herbaceous cover. The presence of much charcoal in the sediment likely suggests a higher incidence of fires at that time. It is unlikely that the H1 tephra particles scorched the vegetation on landing as the source volcanoes are too distant and the tephra would have long cooled in the atmosphere before being deposited on the ground. There has been much debate about the role of natural versus human causes for fire in the landscape (Markgraf et al., 2007). There is sparse evidence for human occupation in the cordilleran region during this period. However, the nature of palaeoenvironmental evidence is such that we cannot identify the source of ignition, but we can infer that the fuel, in this case grassland and Nothofagus, was relatively dry and so drier climatic conditions persisted at that time. The interpretation of drier climatic conditions is further supported by the higher 
Table 3. Phases of human occupation (indicated by grey shading) identified in the Jenimeni-Ghio corridor (from Mengoni Goñalons et al., 2013).

\begin{tabular}{|c|c|c|c|c|c|}
\hline \multirow{2}{*}{$\begin{array}{l}\text { Site } \\
\text { Occupation (cal. BP } 2 \sigma)\end{array}$} & \multicolumn{3}{|c|}{ Lago Ghio-Paso Roballos } & \multicolumn{2}{|l|}{ Rio Jenimeni } \\
\hline & Sol de Mayo I & Lago Columna I & Colmillo Sur I & Alero Mauricio II & La Frontera \\
\hline $315-470$ & & & & & LF-6 \\
\hline $730-1260$ & & & & & LF-5 \\
\hline $2015-3455$ & & & & & LF-4 \\
\hline $6795-7150$ & & & & & LF-2 \\
\hline
\end{tabular}

presence of degraded pollen, which is indicative of drier, more aerobic conditions at the site at that time.

The bluish-grey clays and fine silts, with sporadic pollen content between $c .7420$ and 6480 cal. BP (LF-2), are characteristic of a solifluction deposit, which suggests a shift to colder, periglacial conditions at the higher altitude of the Rio Zeballos valley. The proportion of Nothofagus pollen within the lower level of the clays is perhaps contradictory, but the TLP achieved for this level was $\sim 100$ and it is probable that the Nothofagus came from lower altitude woodland and enriched the reduced site-local pollen input. Towards the top of this section of soliflucted clays, there is a gradual increase in organic content and higher Nothofagus pollen is recorded in a level of organic rich mud suggesting the return of more temperate conditions. However, this was of short duration and there was a rapid, though brief return to periglacial conditions. During LPAZ LF-2, it is likely that the tree-line was lower and the bare ground surrounding the site inhospitable for human occupation except perhaps for short periods during the austral summer months. Nevertheless, at lower elevations in the Paso Roballos area, the rock shelter Sol de Mayo I (c. 6940-6970 cal. BP) is among the earliest archaeological evidence for human occupation during this period (Mengoni Goñalons et al., 2013) (Table 3).

After c. $6480 \mathrm{cal}$. BP, there is a marked transition from the solifluction deposits to more organic rich muds which suggests a shift to more temperate conditions. Initially, Asteraceae and to a lesser extent Caryophyllaceae colonise bare ground, but they again appear to have been out-competed by the Nothofagus woodland and grasses. A rising tree-line/eastwards shift in the foreststeppe ecotone boundary is suggested by the gradual increase in Nothofagus pollen indicating the development of open canopy forest (De Porras et al., 2012) and the reduction in grass pollen. However, this was reversed, the forest cover reduced, and grass pollen increased at c. $5800 \mathrm{cal}$. BP. Drier climatic conditions are inferred from the higher proportions of corroded and degraded pollen, and so it is likely the site lay close to the forest-steppe ecotone boundary at this time. The reduction in tree cover was dramatically accelerated by a fire event at $c .5310$ cal. BP that appears to have reduced Nothofagus pollen from $\sim 70 \%$ to less than $10 \%$ and grasses correspondingly increased. This pattern is replicated in the pollen accumulation rates. This event would have significantly opened up the landscape, which can often be seen in modern fire events in Patagonia. There is limited evidence for human occupations at lower altitudes (300-400 m a.s.l.) and none as yet within the study area during this period of drier conditions and shifting vegetation cover (Table 3 ).

Between c. 5300 and 3700 cal. BP, Nothofagus woodland recovered to form relatively closed-canopy forest with only small grass cover indicated and a shift to more humid conditions is inferred. The increase in effective moisture is further supported by the virtual absence of charcoal during this period and the higher proportion of normal pollen suggesting more anaerobic conditions. There was also a small but significant presence of the aquatic Myriophyllum sp. During this period, the Volcán Hudson $\mathrm{H} 2$ tephra layer (c. $5160 \mathrm{cal}$. BP) is deposited but with no apparent impacts on the pollen record. The archaeological evidence follows the same pattern as in the previous period, in that the occupations are located at lower altitudes and no sites of occupation for this time have been identified in our study area.

At c. 3920 cal. BP, the deposition of an unknown tephra layer is just before a dramatic reduction in woodland cover and an expansion of grasses. There are no charcoal peaks at this time and it is unlikely that a single Andean volcanic eruption could have caused a regional climatic cooling that could have led to such a dramatic loss of tree cover. However, the pattern of change may not be as obvious as the percentage pollen data suggests. There was a gradual reduction in the proportion of normally preserved pollen which started earlier at c. $4500 \mathrm{cal}$. BP (from the middle of LF-4) and this was matched by a trend in reducing Nothofagus pollen accumulation reaching a minima at $c .3500 \mathrm{cal}$. BP. These lines of evidence suggest a more gradual deterioration in climate, perhaps with a lagged response in the Nothofagus cover, which reached a tipping point coincident with and perhaps further stressed by the volcanic eruption and deposition of the tephra layer, which was then followed by the expansion of grasses in response to the opening up of the landscape.

After c. $3500 \mathrm{cal}$. BP, there is a gradual reduction in grasses and a return of Nothofagus forest. More humid-temperate conditions are indicated by the corresponding increase in normally preserved pollen and a rise in the proportion of sedges. This trend is briefly punctuated by a substantial fire event at $c .2670 \mathrm{cal}$. BP. The trend in increasing proportions of Nothofagus pollen was briefly reversed and there is a corresponding increase in grass pollen. At the top of LF-5, a significant increase in effective moisture is inferred from the continued expansion of Nothofagus reaching closed-canopy forest at c. $2100 \mathrm{cal}$. BP and a dramatic peak, though of short duration in Myriophyllum suggesting an increase in standing water at the site. During this period, we see a peak in human activity in the study area (Table 3 ). There are human occupations in both areas of the Jeinemeni-Ghio corridor and there is an increase in the number of places used in the Paso Roballos. Occupations appear to be relatively more intense in the use of lithic and faunal resources and, at a local scale, places are reoccupied showing more persistence and continuity in human activity.

After c. 2100 cal. BP, the dominance of Nothofagus indicates the persistence of humid-temperate conditions with a significant rise in the elevation of the tree-line/eastwards shift in the foreststeppe ecotone boundary. During this LPAZ, the proportion of normally preserved pollen reaches its highest levels and pollen accumulation rates are relatively stable suggesting a uniform rate of sediment accumulation. During this period, there are more places that have human occupation both in our study area and in the neighbouring Chacabuco, Pueyrredón-Posadas and Salitroso basins, although occupations along the Paso Roballos-Río Zeballos valleys are less intense in the use of resources and are less persistent (Mengoni Goñalons et al., 2013).

The majority of published palaeoenvironmental records from central Patagonia suggest that during the early Holocene, the regional pattern of vegetation, in response to increasing humidity and temperature, achieved a climax steady state which few perturbations, climate, volcanic or human, were able to disrupt. In contrast, the palaeoenvironmental record from La Frontera suggests a 
sequence of Holocene environmental changes that have not been visible to us before. This is likely due to the site's high altitude and easterly location close to the tree-line/forest-steppe/ecotone boundary which means it is probably sensitive to relatively small climatic variations in snow cover at higher altitude and to the length of the growing season.

The archaeological sequences in the Jeinemeni valley are closer and more exposed to the fluctuations in the La Frontera core whereas the archaeological sequences in Paso Roballos area are located further away and at a slightly lower altitude. Forest expansion and the eastward displacement of the forest-steppe ecotone boundary would have made natural resources more available to the hunter-gatherers living at lower altitudes and so we would expect to see more evidence for persistent occupation in the Paso Roballos area during such periods. Our synthesis of the La Frontera palaeoenvironmental record and the archaeological records suggests that human occupations in the Paso Roballos area do appear to be more persistent through time than in the Jeinemeni valley. During the more humid-temperate conditions recorded during LF-5, there appears to be more evidence for occupations across the Jeniemeni-Ghio corridor although there are also gaps in the occupation sequences. During the more humid-temperate periods, there also appears to be a change in the intensity of resource use, for example, occupations dating to 2155-3450 cal. BP are more intense in lithic resource use than later periods (795-1280 cal. BP) in the study area (Mengoni Goñalons et al., 2009). It is at this time that there is an increase in the frequency of dated occupations both in our study area and in the adjoining valleys of the river Chacabuco and the PueyrredónPosadas and Salitroso lakes. However, when environmental conditions are either colder or ameliorated there is not necessarily a corresponding change in the presence, persistence or intensity of human occupation in either portion of the corridor.

\section{Conclusion}

The palaeoenvironmental record from La Frontera suggests the site was sensitive to longitudinal shifts in the forest-steppe ecotone and/or altitudinal movements in the Nothofagus tree-line. The onset of the record reflects drier temperate conditions at $c$. 8200 cal. BP which was followed by a dramatic and sustained period of cooling between $c .7400$ and $6500 \mathrm{cal}$. BP characterised by periglacial activity occurring at $\sim 1000 \mathrm{~m}$ a.s.l. This was followed by a gradual return, although punctuated by a further cooling event, to drier temperate conditions that persisted until c. 5300 cal. BP. There followed a shift to more humid conditions and the development of more closed-canopy Nothofagus forest although with several episodes of forest contraction at c. 3470 and 2670 cal. BP. From c. 2100 to 350 cal. BP, more stable and humid conditions prevailed leading to the development of stable closedcanopy Nothofagus forest.

To understand better the human-environment dynamic, this project has brought together the reconstruction of landscape change through palaeoenvironmental techniques with the record of human occupation in the Paso Roballos-Río Jeinemeni study area. Despite the differences in spatial and temporal scales, we are able to see that the first period of occupation identified in the archaeological record took place, albeit at a lower altitude, during the period of significant cooling between $c .7400$ and $6500 \mathrm{cal}$. BP. The later phases of occupation occur at a time of more temperate climate, increased woodland resources and greater frequency of fires.

\section{Acknowledgements}

The authors would like to thank Dr Pauline Gulliver for her help in the processing of radiocarbon samples. Tephra analytical support was provided by the Scottish Alliance for Geoscience,
Environment and Society (SAGES) and the authors are grateful to Dr Chris Hayward at the University of Edinburgh Tephra Analytical Unit and to Dr Anthony Newton for their assistance. The authors would like to thank Flavia Morello, Fraser MacDonald, Euan Robertson, Milva Umaño, Dr Vicky Fernández and the Estancias, El Álamo, La Frontera and Sol de Mayo, for their assistance in the fieldwork. The authors would also like to thank Professor Vera Markgraf and two anonymous referees for their constructive comments.

\section{Funding}

This project was completed with the support from the Universidad de Buenos Aires (UBACYT 2008-2011) (F061) and Agencia Nacional de Promoción Científica y Tecnológica (PICT-ANPYCT 2008-2011) (00668). Radiocarbon support was provided by the Natural Environmental Research Council - Radiocarbon Laboratory, East Kilbride (SUERC) (Allocation: 1696-0413).

\section{References}

Berglund BE and Ralska-Jasiewiczowa M (1986) Pollen analysis and pollen diagrams. In: Berglund BE (ed.) Handbook of Holocene Palaeoecology and Palaeohydrology. Chichester: Wiley, pp. 455-484.

Blaauw M (2010) Methods and code for 'classical' age-modelling of radiocarbon sequences. Quaternary Geochronology 5: 512-518.

Bunting MJ and Tipping R (2000) Sorting dross from data: Possible indicators of postdepositional assemblage biasing in archaeological palynology. In: Bailey G, Charles R and Winder N (eds) Human Ecodynamics. Oxford: Oxbow Books, pp. 63-69.

De Porras ME, Maldonado A, Abarzúa AM et al. (2012) Postglacial vegetation, fire and climate dynamics at Central Chilean Patagonia (Lake Shaman, $44^{\circ} \mathrm{S}$ ). Quaternary Science Reviews 50: 71-85.

De Porras ME, Maldonado A, Quintana A et al. (2014) Environmental and climatic changes in central Chilean Patagonia since the Late Glacial (Mallín El Embudo, $44^{\circ} \mathrm{S}$ ). Climate of the past 10: 1063-1078.

Dugmore AJ, Larsen G and Newton AJ (1995) Seven tephra isochrones in Scotland. The Holocene 5: 257-266.

Dugmore AJ, Larsen G, Newton AJ et al. (1992) Geochemical stability of fine-grained silicic tephra layers in Iceland and Scotland. Journal of Quaternary Science 7: 173-183.

Figuerero Torres MJ and Mengoni Goñalons GL (2010) Lugares persistentes y vacíos ocupacionales en sociedades cazadorasrecolectoras de la Patagonia Centro-Meridional. In: Actas del XVII Congreso Nacional de Arqueología Chilena - Valdivia 9-14 October 2006, vol. 2, pp. 1319-1330. Valdivia: Ediciones Kultrún.

Garreaud R, Lopez P, Minvielle M et al. (2013) Large-scale control on the Patagonian climate. Journal of Climate 26: 215-230.

Gilli A, Ariztegui D, Anselmetti FS et al. (2005) Mid-Holocene strengthening of the Southern Westerlies in South America - Sedimentological evidences from Lago Cardiel, Argentina (49 ${ }^{\circ}$ S). Global and Planetary Change 49: 75-93.

Glasser NF, Jansson KN, Duller GAT et al. (2016) Glacial lake drainage in Patagonia (13-8 kyr) and response of the adjacent Pacific Ocean. Scientific Reports 6: 21064.

Grimm EC (1987) CONISS: A Fortran 77 program for stratigraphically constrained cluster analysis by the method of incremental sum of squares. Computers \& Geosciences 13: 13-35.

Haberle SG and Bennett K (2004) Postglacial formation and dynamics of North Patagonian Rainforest in the Chonos Archipelago, Southern Chile. Quaternary Science Reviews 23: $1523-1548$. 
Hayward C (2011) High spatial resolution electron probe microanalysis of tephras and melt inclusions without beam-induced chemical modification. The Holocene 22: 119-125.

Heusser CJ (1971) Pollen and Spores from Chile: Modern Types of Pteridophyta, Gymnos-permae and Angiospermae. Tucson, AZ: University of Arizona Press.

Heusser CJ (1995) Three Late Quaternary pollen diagrams from Southern Patagonia and their palaeoecological implications. Palaeogeography, Palaeoclimatology, Palaeoecology 118: $1-24$.

Hogg AG, Hua Q, Blackwell PG et al. (2013) SHcal13 southern hemisphere calibration, $0-50,000$ years cal BP. Radiocarbon 55: 1889-1903.

Horta LR, Marcos MA, Bozzuto DL et al. (2016) Paleogeograhic and paleoenvironmental variations in the area of the Pueyrredón, Posadas and Salitroso lakes, Santa Cruz Province, Argentina, during the Holocene and its relationship with occupational dynamics. Palaeogeography, Palaeoclimatology, Palaeoecology 449: 541-552.

Hunt JB and Hill PG (1993) Tephra geochemistry: A discussion of some persistent analytical problems. The Holocene 3: 271-278.

Jowsey PC (1966) An improved peat sampler. New Phytologist 65: $245-248$

McCulloch RD (2011) Westerlies and their effects on maritime ice caps and glaciers. In: Singh VP, Singh P and Haritashya UK (eds) Encyclopedia of Snow, Ice and Glaciers (Encyclopedia of earth sciences series). Dordrecht: Springer, pp. 1224-1227.

McCulloch RD and Bentley MJ (1998) Lateglacial ice advances in the Strait of Magellan, southern Chile. Quaternary Science Reviews 17: 775-787.

McCulloch RD and Davies SJ (2001) Late-glacial and Holocene palaeoenvironmental change in the central Strait of Magellan, southern Patagonia. Palaeogeography, Palaeoclimatology, Palaeoecology 173: 143-173.

McCulloch RD, Fogwill CJ, Sugden DE et al. (2005) Chronology of the last glaciation in the central Strait of Magellan and Bahía Inútil, southernmost South America. Geografiska Annaler 87A: 289-312.

Mancini MV, Páez MM, Proeto AR et al. (2005) Mid-Holocene climatic variability reconstruction from pollen records $\left(32^{\circ}-\right.$ $52^{\circ} \mathrm{S}$, Argentina). Quaternary International 132: 47-59.

Markgraf V and D'Antoni HL (1978) Pollen Flora of Argentina: Modern Spore and Pollen Types of Pteridophyta, Gymnospermae, and Angiospermae. Tucson, AZ: University of Arizona Press.

Markgraf V, Whitlock C and Haberle S (2007) Vegetation and fire history during the last 18,000 cal yr B.P. in Southern Patagonia: Mallín Pollux, Coyhaique, Province Aisén $\left(45^{\circ} 41^{\prime} 30^{\prime \prime} \mathrm{S}\right.$, $71^{\circ} 50^{\prime} 30^{\prime \prime} \mathrm{W}, 640 \mathrm{~m}$ elevation). Palaeogeography, Palaeoclimatology, Palaeoecology 254: 492-507.
Mengoni Goñalons GL, Fernández MV and Figuerero Torres MJ (2013) Tiempo y movilidad en el área de Los Antiguos-Monte Zeballos y Paso Roballos, Santa Cruz, Argentina. In: Zangrando AF, Barberena R, Gil A et al. (eds) Tendencias teóricometodológicas y casos de estudio en la arqueología de la Patagonia. Buenos Aires: Museo de Historia Natural de San Rafael \& INAPL, pp. 441-449.

Mengoni Goñalons GL, Figuerero Torres MJ, Fernández MV et al. (2009) Carácter de las ocupaciones humanas en el área de Los Antiguos-Monte Zeballos y Paso Roballos (Santa Cruz, Argentina). In: Salemme M, Santiago F, Álvarez M et al. (eds) Arqueología de Patagonia: una mirada desde el último confin, vol. II. Ushuaia: Editorial Utopías, pp. 1061-1074.

Moore PD, Webb JA and Collinson ME (1991) Pollen Analysis. 2nd Edition. Oxford: Blackwell.

Moreno PI (1997) Vegetation and climate near Lago Llanquihue in the Chilean Lake District between 20200 and 9500 C-14 yr BP. Journal of Quaternary Science 12: 485-500.

Moreno PI and León AL (2003) Abrupt vegetation changes during the last glacial to Holocene transition in mid-latitude South America. Journal of Quaternary Science 18: 787-800.

Moy CM, Dunbar RB, Moreno PI et al. (2008) Isotopic evidence for hydrologic change related to the westerlies in SW Patagonia, Chile, during the last millennium. Quaternary Science Reviews 27: 1335-1349.

Naranjo JA and Stern CR (1998) Holocene explosive activity of Hudson Volcano, southern Andes. Bulletin of Volcanology 59: 291-306.

Naranjo JA and Stern CR (2004) Holocene tephrochronology of the southernmost part $\left(42^{\circ} 30^{\prime}-45^{\circ} \mathrm{S}\right)$ of the Andean Southern Volcanic Zone. Revista Geológica de Chile 31: 225-240.

Prieto A, Stern CR and Estévez JE (2013) The peopling of the Fuego-Patagonian fjords by littoral hunter-gatherers after the mid-Holocene $\mathrm{H} 1$ eruption of the Hudson volcano. Quaternary International 317: 3-13.

Stern CR, Moreno PI, Henríquez WI et al. (2016) Holocene tephrochronology around Cochrane $\left(\sim 47^{\circ} \mathrm{S}\right)$, southern Chile. Andean Geology 43: 1-19.

Stockmarr J (1971) Tablets with spores used in absolute pollen analysis. Pollen et Spores 13: 615-621.

Stuiver M and Reimer PJ (1993) Extended ${ }^{14} \mathrm{C}$ database and revised CALIB $3.0{ }^{14} \mathrm{C}$ age calibration program. Radiocarbon 35: $215-230$

Tipping R (1987) The origins of corroded pollen grains at 5 early post glacial pollen sites in western Scotland. Review of Palaeobotany and Palynology 35: 151-161.

Villa-Martínez R, Moreno PI and Valenzuela MA (2012) Deglacial and postglacial changes on the eastern slopes of the central Patagonian Andes $\left(47^{\circ} \mathrm{S}\right)$. Quaternary Science Reviews 32: 86-99. 